\title{
Pengaruh Gaya Kepemimpinan Konsultatif dan Tuntutan Tugas Terhadap Komitmen Organisasi pada PT. Bank Mandiri (Persero) Cabang Banda Aceh
}

\author{
Syamsul Rizal
}

Dosen Akademi Keuangan dan Perbankan (AKUBANK) Nusantara dan Mahasiswa Program Pasca Sarjana Doktor Ilmu Manajemen (DIM) Universitas Syiah Kuala Banda Aceh

\begin{abstract}
Abstrak. Tujuan penelitian ini adalah untuk mengetabui pengaruh gaya kepemimpinan konsultatif dan tuntutan tugas terhadap komitmen organisasi karyawan di PT. Bank Mandiri (Persero) Cabang Banda Aceh dan untuk mengetahui seberapa besarpengarub kepemimpinan dan tuntutan tugas tehadap komitmen organisasi karyawan di PT. Bank. Mandiri (Persero) Cabang Banda Aceh. Penelitian ini dilakukan pada PT. Bank. Mandiri (Persero) Cabang Banda Aceh. Objek penelitian ini adalah selurub karyawan pada PT. Bank Mandiri (Persero) Cabang Banda Aceh. Penelitian ini akan menyajikan tentang bagaimana pengarub kepemimpinan dan tuntutan tugas, terbadap komitmen organisasi karyawan pada PT. Bank Mandiri (Persero) Cabang Banda Aceh, dengan jumlah responden sebanyak 47 orang. Berdasarkan hasil uji-F (simultan) menunjukkan babwa semua variabel yang diteliti mempunyai pengarub yang signifikan terhadap peningkatan komitmen karyawan PT. Bank Mandiri (Persero) Cabang Banda Aceh dengan nilai $F_{\text {bitung }}>F_{\text {tabel, }}$ pada tingkat signifikeansi $=5 \%$. Berdasarkan hasil uji-t (secara parsial) variabel yang sangat signifikan berpengaruh terbadap komitmen karyawan PT. Bank. Mandiri (Persero) Cabang Banda Aceh adalab variabel tuntutan tugas dengan diperoleb nilai thitung lebih besar dibandingkan dengan variabel kepemimpinan konsultatif mempunyai nilai thitung yang lebih kecil.
\end{abstract}

Kata kunci: Tuntutan Tugas, Kepemimpinan dan Komitmen Organisasi.

\begin{abstract}
The purpose of this study was to determine the effect of consultative leadership style and task demands on organizational commitment of employees at PT. Bank. Mandiri (Persero) Banda Aceh Branch and to find out how much influence leadership and the demands of the task of employee organizational commitment at PT. Bank. Mandiri (Persero) Banda Aceh Branch. This research was conducted at PT. Bank. Mandiri (Persero) Banda Aceh Branch. The object of this research is all employees at PT. Bank Mandiri (Persero) Banda Aceh Branch. This study will present how the influence of leadership and the demands of the task, on organizational commitment of employees at PT. Bank Mandiri (Persero) Banda Aceh Branch, with a total of 47 respondents. Based on the results of the F-test (simultaneous), it shows that all the variables studied have a significant effect on increasing the commitment of employees of PT. Bank Mandiri (Persero) Banda Aceh Branch with a value of $F_{c o u n t}>F_{\text {table, at a significance level }}$ $=5 \%$. Based on the results of the t-test (partially) the variables that have a significant effect on the commitment of the employees of PT. Bank Mandiri (Persero) Banda Aceb Branch is a task demand variable with a t-count value greater than the consultative leadership variable having a smaller t-count value.
\end{abstract}

Keywords: Task demands, leadership and organizational commitment.

*Corresponding author. Email: syamsulrizal@akubanknusantara.ac.id

Received: 9 September 2018, Revision: 20 Nopember 2018, Accepted: 18 Desember 2018

Print ISSN: 2579-7972; Online ISSN: 2549-6204.

Copyright@ 2018. Published by Divisi Riset, Lembaga KITA. 


\section{Pendahuluan}

Efektivitas seorang pemimpin ditentukan oleh kepiawaiannya untuk mempengaruhi dan mengarahkan para anggotanya. dalam kenyataannya pemimpin dapat mempengaruhi semangat dan kegairahan kerja, adanya tuntutan tugas yang keras dan berat akan dapat menimbulkan stress kerja, untuk itu dalam menghadapi pekerjaannya, seseorang harus dapat mengelola kondisi stres kerjanya dengan sebaik mungkin. Namun demikian stres kerja tidak selamanya akan mengganggu aktivitas seseorang dan bahkan memacu kinerjanya dan pada akhirnya dapat menimbulkan kepuasan kerja. Terkait dengan gaya pemimpin pada PT. Bank Mandiri (Persero) Cabang Banda Aceh yang belum sepenuhnya mencerminkan kepemihakan kepada karyawan dalam meningkatkan kepuasan kerja. Pemimpin masih menerapkan gaya instruksi, padahal gaya kepemimpinan partisipatif lebih dalam meningkatkan kepuasan kerja, sehingga mempengaruhi komitmen organisasi bagi karyawan.

Pimpinan PT. Bank Mandiri (Persero) Cabang Banda Aceh belum berani mengambil risiko dengan gaya apapun yang dilakukan terhadap keberhasilan organisasi yang kontruktif di bank tersebut, terutama dalam hubungan dengan karyawan dan melakukan kegiatan perbankan dengan penuh kreatif dan semangat tinggi. Ia harus memiliki penilaian tugas terhadap setiap kegiatan yang dilakukan oleh karyawannya untuk melakukan evaluasi supaya hasil kerja dapat tercapai dengan baik sebagaimana yang diharapkan oleh pihak perusahaan.

Objek penelitian ini adalah karyawan yang bekerja pada PT. Bank Mandiri (Persero) Cabang Banda Aceh. Alasan dipilihnya sebagai objek penelitian di PT. Bank Mandiri (Persero) Cabang Banda Aceh adalah karena keberadaan karyawan bersinggungan secara langsung dengan para nasabah dan karyawan sebagai tenaga perbankan dapat membawa citra PT. Bank Mandiri (Persero) Cabang Banda Aceh yang bersangkutan dan tenaganya sangat dibutuhkan oleh nasabah terutama yang berkenaan dengan masalah perbankan. Para karyawan PT. Bank Mandiri (Persero) Cabang Banda Aceh, dituntut untuk memiliki kemauan dan kemampuan untuk mengembangkan ketrampilan dan pengetahuannya dalam usaha untuk memberikan pelayanan yang berkualitas kepada setiap nasabah. Di samping itu seorang karyawan dituntut untuk mampu memberikan pelayanan yang ramah, sopan serta trampil, sehingga dapat mengurangi keluhan nasabah. Tuntutan loyalitas bagi seorang karyawan sangat diperlukan misalnya untuk melakukan tugas lainnya apabila dibutuhkan oleh pihak PT. Bank Mandiri (Persero) Cabang Banda Aceh. Mengingat begitu khasnya tugas seorang karyawan, maka perlu memperhatikan berbagai aspek yang dapat mempengaruhi stres kerjanya sehingga dampak pada komitmen organisasinya menjadi positif Seorang karyawan mempunyai kontribusi yang tidak kalah pentingnya dalam usaha untuk memberikan pelayanan terbaik kepada setiap nasabah yang berurusan dengan pihak bank.

\section{Tinjauan Literatur}

Kepemimpinan dapat diartikan kemampuan mendorong sejumlah orang agar bekerja sama dalam melaksanakan kegiatan-kegiatan yang terarah pada tujuan bersama. Menurut Wahjosumidjo (2002 : 27), menyatakan bahwa "Kepemimpinan adalah hubungan di mana satu orang yakni pimpinan mempengaruhi pihak lain untuk bekerja sama dalam usaha mengerjakan tugas-tugas yang berhubungan, untuk mencapai hal ᄀ-hal yang diinginkan oleh pimpinan tersebut". Sedangkan Siagian. (2003 - 8) menyatakan bahwa: "Kepemimpinan adalah suatu kemampuan seseorang meyakinkan orang lain sehingga dapat diarahkan maksimal untuk melaksanakan tugas-tugas tertentu". Kepemimpinan itu perlu dimiliki oleh stiap calon pimpinan. Menurut Garvin (2000 4) "keberadaan pimpinan dalam perusahaan sebenarnya lebih dari sekedar menajer. Selain kegiatannya berorientasi pada tindakan, pendelegasikan dan keputusan-keputusan, keberadaan pimpinan dalam perusahaan harus memiliki wawasan kedepan dengan menyusun target, mengembangkan strategi dan mengkomunikasikan visi dan misi perusahaan" Selanjutnya Saydan (2006 : 199) menyatakan ciriciri pimpinan yang efektif adalah:

1. Cakap, mempunyai kecakapan lebih tinggi dari pada karyawan.

2. Mempunyai sikap kedewasaan sosial yang luas, 
seorang pimpinan seharusnya mempunyai sifat yang terbuka pada masyarakat dan mempunyai perhatian terhadap kegiatankegiatan sosial.

3. Mempunyai motivasi dan cita-cita yang tinggi, seorang pimpinan ingin menyelesaikan sesuatu, ingin mencoba berbagai cara untuk menyelesaikan satu masalah.

4. Mempunyai sikap suka berhubungan dengan orang lain, seorang pimpinan harus dapat bekerja dengan orang lain. Dia menghargai orang lain dan dia sadar bahwa untuk menyelesaikan satu tugas dia harus pertimbangkan orang lain.

\section{Gaya Kepemimpinan}

1. Gaya Kepemimpinan Delegasi

Hersey dan Blanchard (2005 : 87), Gaya kepemimpinan delegasi merupakan perilaku tugas rendah dan pola perilaku tenggang rasa rendah (G.4) karyawan di biarkan bekerja sesuai dengan kemauannya sendirisendiri, tanpa diberi petunjuk, tanpa pembagian pekerjaan yang jelas, tanpa diawasi, tanpa koordinasi satu sama lainnya. Dengan kata lain, karyawan dibiarkan bekerja tanpa rencana dan arah yang jelas. Dalam hal ini pemimpin (kepala) sama sekali tidak melaksanakan fungsinya sebagai pemimpin.

2. Gaya Kepemimpian Partisipatif

Gaya kepemimpinan partisipatif merupakan pola perilaku tugas rendah dan pola hubungan manusia tinggi (G.3) kepemimpinan gaya partisipatif benar-benar memperhatikan kesejahteraan karyawan, dan berupaya untuk mengembangkan potensi mereka agar dapat mencapai pertumbuhan secara maksimal baik pertumbuhan pribadi (personal growth) maupun pertumbuhan jabatan (Professional Growth).

3. Gaya Kepemimpinan Konsultasi

Gaya kepemimpinan konsultasi merupakan pola perilaku tugas tinggi dan pola perilaku hubungan manusia tinggi (G. 2). Kepemimpinan gaya konsultasi mendapat perhatian yang besar sekali dalam upaya meningkatkan produktivitas dan kesejahteraan karyawan maupun pada tercapainya tujuan organisasi secara maksimal. Winardi (2000 136) mengatakan bahwa gaya kepemimpinan ini menghasilkan secara optimal dalam suatu organisasi, dan sangat efektif dalam meningkatkan kinerja bawahan.

4. Gaya Kepemimpinan Instruksi

Instruksi adalah suatu gaya kepemimpinan yang ditandai dengan pola perilaku tugas tinggi dan pola perilaku perhatian terhadap manusia rendah (G. 4) instruksi gaya kepemimpinan dalam segala pola perilaku bersifat direktif, mengutamakan status formal (legitimate power) yang di dudukinya, dan perhatian penuhnya di pusatkan pada tercapainya tujuan secara maksimal dengan sedikit sekali memperhatikan kebutuhan karyawan.

Blacke dan Mouton (2004 : 136) mengatakan bahwa perhatian pemimpin terhadap bawahannya kecil tetapi perhatiannya terarah pada pekerjaannya. Aplikasi gaya kepemimpinan instruktif di pengaruhi ancaman motivasi tradisional (coercion model motivation) yang cendrung besifat kaku: "bekerja dengan baik atau dihukum", karena sifat yang cendrung menekan, karyawan dalam bekerja membuat suasana penuh dengan ketegangan dan ketakutan yang terus $\neg$ menerus yang pada gilirannya akan berakibatkan menurunnya produktivitas kerja karyawan.

Kemudian Winardi (2000 : 215) mengemukakan gaya kepemimpinan instruktif sering kali menghadapi resiko timbulnya perasaan menentang diantara karyawan, mereka terutama apabila melaksanakan gaya kepemimpinan tersebut secara berlebihan antara bawahan yang "kuat" yang juga berkeinginan untuk menjalankan otoritas mereka. Selanjutnya Strauss dan Jayless (2006 : 44) mengatakan bahwa meskipun karyawan dapat di paksa untuk patuh dengan ancaman motivasi tradisional, frustasi yang menjadi konsekuensinya bisa mengakibatankan kemorosotan yang serius pada mutu pekerjaan mereka dan berperilaku yang kurang baik.

\section{Peranan dan Tugas Pimpinan}

Belakangan ini, lingkungan perusahaan menghadapi perubahan yang sangat cepat dan akan berdampak terhadap semakin kompletnya sistem kerja dalam perusahaan. Kondisi ini akan 
berdampak terhadap prilaku-prilaku karyawan yang bekerja dalam perusahaan. Oleh sebab itu diperlukan kepemimpinan yang mampu beradaptasi dan mampu dan mengatasi berbagai masalah-masalah dalam perusahaan.

\section{Komitmen Organisasi}

Menurut Mowday dan Steers (2002), komitmen organisasi menggambarkan seberapa jauh seseorang itu mengidentifikasikan dan melibatkan dirinya pada organisasinya dan keinginan untuk tetap tinggal di organisasi itu. Sikap ini dapat ditandai dengan tiga hal, yaitu:

1. Kepercayaan yang kuat dan penerimaan terhadap nilai-nilai dan tujuan organisasi.

2. Kesediaan untuk berusaha dengan sungguhsungguh atas nama organisasi.

3. Keinginan yang kuat untuk mempertahankan keanggotaan di dalam organisasi.

Menurut Steers dan Porter (2002 - 520), suatu bentuk komitmen kerja yang muncul bukan hanya bersifat loyalitas yang pasif, tetapi juga melibatkan hubungan yang aktif dengan organisasi kerja yang memiliki tujuan memberikan segala usaha demi keberhasilan organisasi kerja yang bersangkutan. Mowday (2002 : 64) mendefinisikan komitmen kerja sebagai kekuatan relatif dari identifikasi individu dan keterlibatannya dengan organisasi kerja. Sementara Mitchell (2002 - 136) memandang komitmen kerja sebagai suatu orientasi nilai terhadap kerja yang menunjukkan bahwa individu sangat memikirkan pekerjaannya, pekerjaan memberikan kepuasan hidup, dan pekerjaan memberikan status bagi individu. Selanjutnya Steers dan Porter (2002 : 525) mengemukakan adanya tiga karakteristik yang bisa digunakan sebagai pedoman telah komitmen kerja, yaitu :

a. Adanya keyakinan yang kuat dan penerimaan tujuan serta nilai-nilai yang dimiliki organisasi kerja.

b. Terdapatnya keinginan untuk mempertahankan diri agar tetap dapat menjadi anggota organisasi tersebut.

c. Adanya kemauan untuk berusaha keras sebagai bagian dari organisasi kerja.

\section{Membangun Loyalitas dan Komitmen}

Menurut Steers (dalam Dessler, 2000 : 319) komitmen organisasi dapat didefinisikan sebagai kekuatan relatif identifikasi individu terhadap organisasinya, yang dapat dilihat paling tidak dengan 3 faktor, yaitu :

1. Kepercayaan dan penerimaan yang kuat atas tujuan dan nilai-nilai organisasi.

2. Kemauan untuk mengusahakan kepentingan organisasi.

3. Keinginan yang kuat untuk mempertahankan jadi anggota organisasi.

Komitmen organisasi sebagai suatu sikap karyawan, bagaimanapun juga akan menentukan perilakunya sebagai perwujudan dari sikap (gambar 1).

actions/decisions)

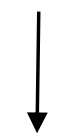

ATTITUDES

(inclination to act)

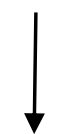

VALUES

(basic beliefs)

Gambar 1. Hubungan Antara Nilai, Sikap dan Perilaku

Sumber: Keith Davis, William Frederick, 2001

\section{Hasil Penelitian terkait}

Penelitian sebelumnya yang relevan dengan penelitian ini adalah penelitian yang dilakukan oleh Koesmono, (2007), dengan judul Pengaruh Kepemimpinan dan Tuntutan Tugas Terhadap Komitmen Organisasi Dengan Variabel Moderasi Motivasi Perawat Rumah Sakit Swasta Surabaya, dimana hasil penelitian ini menunjukkan bahwa kepemimpinan dan tuntutan tugas mempengaruhi stress kerja, begitu pula berpengaruh terhadap komitmen organisasi.

Penelitian ini memiliki kesamaan dan perbedaan dengan penelitian sebelumnya yang telah diuraikan di atas. Persamaan dan perbedaan tersebut dapat dilihat dalam tabel berikut. 
Tabel 1. Perbedaan dan Persamaan Penelitian Dengan Penelitian Sebelumnya

\begin{tabular}{|c|c|c|}
\hline No. & Penelitian ini & Penelitian Sebelumnya \\
\hline \multirow[t]{9}{*}{1.} & Pengaruh Gaya Kepemimpinan & Pengaruh Kepemimpinan \\
\hline & Konsultatif Dan Tuntutan Tugas & Tugas Terhadap \\
\hline & Terhadap Komitmen Organisasi & Organisasi Dengan \\
\hline & Pada PT. Bank Mandiri (Persero) & Motivasi Perawat \\
\hline & Cabang Banda Aceh & Rumah Sakit Swasta Surabaya, H. \\
\hline & 1. Kepemimpinan & Teman Koesmono, (2007) \\
\hline & 2. Tuntutan Tugas & 1. Kepemimpinan dan \\
\hline & 3. Jumlah responden & 2. Tuntutan tugas \\
\hline & 4. Lokasi Penelitian & 3. Model analisis \\
\hline
\end{tabular}

\section{Hipotesis Penelitian}

H1 : Gaya Kepemimpinan Konsultatif berpengaruh secara signifikan terhadap komitmen organisasi karyawan pada PT. Bank Mandiri (Persero) Cabang Banda Aceh

H2 : Tuntutan tugas berpengaruh secara signifikan terhadap komitmen organisasi karyawan pada PT. Bank Mandiri (Persero) Cabang Banda Aceh

H3 : Gaya Kepemimpinan dan Tuntutan tugas secara simultan berpengaruh secara signifikan terhadap komitmen organisasi karyawan pada PT. Bank Mandiri (Persero) Cabang Banda Aceh

\section{Metodologi Penelitian}

\section{Lokasi Penelitian}

Penelitian ini dilakukan pada PT. Bank Mandiri (Persero) Cabang Banda Aceh. Penelitian ini akan menyajikan tentang bagaimana pengaruh kepemimpinan dan tuntutan tugas, terhadap komitmen organisasi karyawan pada PT. Bank Mandiri (Persero) Cabang Banda Aceh.

\section{Populasi dan penarikan sampel}

Populasi merupakan wilayah generalisasi yang terdiri atas objek/subjek yang mempunyai kuantitas dan karakteristik tertentu yang ditetapkan oleh peneliti untuk dipelajari dan kemudian ditarik kesimpulan, populasi dalam penelitian ini adalah seluruh karyawan PT. Bank Mandiri (Persero) Cabang Banda Aceh yang berjumlah 47 karyawan. Menurut Arikunto,
(2006) untuk sampel apabila subjeknya kurang dari 100, lebih baik diambil semua sehingga penelitiannya merupakan penelitian populasi, dan jika subjeknya besar dapat di ambil antara 10-15\% atau 20-25\%, atau lebih Berdasarkan pendapat tersebut maka akan dilakukan sensus atau mengambil seluruh jumlah karyawan PT. Bank Mandiri (Persero) Cabang Banda Aceh yang berjumlah 47 untuk dijadikan populasi.

\section{Teknik Pengumpulan Data}

Teknik pengumpulan data dalam penelitian ini menggunakan dua metode pengumpulan data, yaitu :

1. Data primer, yaitu data yang dikumpulkan langsung oleh penulis melalui kuesioner yang terdiri dari item-item pertanyaan yang dibagikan kepada karyawan PT. Bank Mandiri (Persero) Cabang Banda Aceh.

2. Data skunder, yaitu data yang diperoleh dari dokumentasi PT. Bank Mandiri (Persero) Cabang Banda Aceh.

\section{Peralatan Analisis Data}

Metode analisis data yang digunakan adalah menggunakan model persamaan linier berganda dengan dua variabel bebas dan satu variabel terikat (Regresi Linier Berganda) yang dinyatakan sebagai berikut, (Umar, 2001 : 180):

$$
\mathrm{Y}=\mathrm{a}+\mathrm{b} 1 \mathrm{X} 1+\mathrm{b} 2 \mathrm{X} 2+\mathrm{e}
$$

Dimana

$$
\begin{array}{ll}
\mathrm{Y} & =\text { Komitmen Organisasi } \\
\mathrm{a} & =\text { Konstanta } \\
\mathrm{b} & =\text { Parameter (koefisien regresi) } \\
\mathrm{x} 1 & =\text { Gaya Kepemimpinan Konsultatif } \\
\mathrm{x} 2 & =\text { Tuntutan Tugas } \\
\mathrm{e} & =\text { Tingkat kesalahan (error) }
\end{array}
$$


Selanjutnya untuk mengetahui tingkat keeratan hubungan antara variabel bebas (x1, x2) dengan variabel terikat $(\mathrm{Y})$ secara partial digunakan aalisis korelasi dengan mencari partial dan untuk melihat berapa besar pengaruh Gaya Kepemimpinan Konsultatif dan tuntutan tugas terhadap komitmen organisasi karyawan secara keseluruhan digunakan koefisien determinasi.

\section{Operasional Variabel}

Tabel 2. Operasional Variabel

\begin{tabular}{|c|c|c|c|c|c|c|}
\hline No & Variabel & Definisi Variabel & Indikator & $\begin{array}{c}\text { Skala } \\
\text { Pengukuran }\end{array}$ & Skala & $\begin{array}{c}\text { Item } \\
\text { Pertan yaan }\end{array}$ \\
\hline \multicolumn{7}{|c|}{ Independent } \\
\hline 1 & $\begin{array}{l}\text { Gava } \\
\text { Kepemimpinan } \\
\text { Konsultatif } \\
\left.\text { ( } \mathrm{x}_{1}\right)\end{array}$ & $\begin{array}{l}\text { pola perilaku tugas tinggi } \\
\text { dan pola perilaku } \\
\text { hubungan manusia tingeg, } \\
\text { Winardi (2000) }\end{array}$ & $\begin{array}{l}\text { - Bimbingan } \\
\text { - Jalan keluar } \\
\text { - Prosedur } \\
\text { - Kebijaksanaa } \\
\text { - Kesepakatan }\end{array}$ & $1-5$ & Interval & $\mathrm{A} 1-\mathrm{A} 5$ \\
\hline 2 & $\begin{array}{l}\text { Tuntutan } \\
\text { Tugas }\left(\mathrm{x}_{2}\right)\end{array}$ & 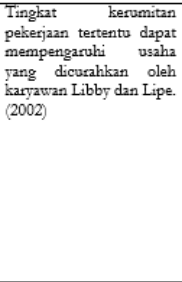 & 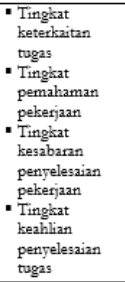 & I -5 & Interval & B1-B4 \\
\hline \multicolumn{7}{|c|}{ Dependen } \\
\hline 3 & $\begin{array}{l}\text { Komitmen } \\
\text { Organisasi } \\
\text { Karyawan }(Y)\end{array}$ & $\begin{array}{l}\text { Menggambarkan } \\
\text { seberapa jauh seseorang } \\
\text { itumengidentikikasikan } \\
\text { dan melibatkan } \\
\text { dirinya pada } \\
\text { organisasiny dan } \\
\text { keinginan untuk tetap } \\
\text { tinggal di organisasi itu. } \\
\text { Steers dan Porter(2002) }\end{array}$ & $\begin{array}{l}\text { - Tinglat } \\
\text { kepercayaan } \\
\text { - Pekerjaan } \\
\text { kurang menarik } \\
\text { - Nama baik } \\
\text { - perusahaan } \\
\text { - Sikap } \\
\text { karyaawan }\end{array}$ & $1-5$ & Interval & $\mathrm{C} 1-\mathrm{C} 4$ \\
\hline
\end{tabular}

\section{Pengujian Hipotesis}

$$
\begin{aligned}
& \text { Ha1 = Gaya } \\
& \text { Konsultatif berpengaruh }
\end{aligned}
$$

$\mathrm{Ha} 2=$ Tuntutan tugas berpengaruh terhadap komitmen organisasi karyawan PT. Bank Mandiri (Persero) Cabang Banda Aceh.

Pengujian hipotesa pada variabel independen dilakukan dengan mengunakan uji statistik t dan uji statistik F. Untuk menguji hasil regresi terhadap hipotesa secara parsial digunakan uji t. Sedangkan untuk melihat apakah variabel independen mempunyai pengaruh terhadap variabel dependen secara keseluruhan digunakan uji F. Dasar pengambilan keputusan dengan membandingkan nilai statistik hitung dengan nilai statistik tabel. Apabila nilai statistik $\mathrm{F}_{\text {hitung }}>\mathrm{F}_{\text {tabel, }}$ maka hipotesis alternatif $\mathrm{Ha}$ diterima dan apabila signifikan $F_{\text {hitung }}<\mathrm{F}_{\text {tabel, }}$, maka hipotesis null (Ho) ditolak, dengan tingkat kepercayaan $95 \%$.

\section{Uji Reliabilitas dan Validitas Uji Reliabilitas}

Reliabilitas digunakan untuk mengetahui apakah alat pengumpulan data telah menunjukkan tingkat ketepatan, keakuratan, atau konsistensi alat tersebut dalam mengungkapkan gejala tertentu dari sekelompok individu, walaupun dilakukan pada waktu berbeda. Menurut Malhotra (1996) koefisien cronbach alpha yang dapat diterima diatas 0,60 .

\section{Uji Validitas}

Validitas menujukkan keandalan yang menggambarkan tingkat instrumen yang bersangkutan mampu mengukur apa yang akan diukur (Arikunto, 2002: 119). Penentuan validitas didasarkan atas perbandingan nilai korelasi yang diperoleh antara skor item dengan skor total item, dengan nilai kritis korelasi product moment ( $\mathrm{r}$ tabel). Apabila nilai korelasi hitung ( $\mathrm{r}$ hitung) lebih besar bila dibandingkan dengan nilai $\mathrm{r}$ tabel pada tingkat keyakinan 95 persen dapat diartikan bahwa item-item pernyataan tersebut valid.

\section{Uji Asumsi Klasik}

Uji asumsi klasik ini dilakukan untuk mengetahui apakah model estimasi yang dipergunakan memenuhi asumsi regresi linear klasik. Hal ini penting dilakukan agar diperoleh parameter yang valid dan handal. Uji asumsi klasik terdiri dari:

a. Uji Normalitas

Uji ini digunakan untuk mengetahui apakah data yang diteliti berdistribusi normal atau tidak. Apabila pada suatu indikator ada yang tidak normal, maka akan dicari tanggapan responden yang menyebabkan ketidak normalan tersebut dan akan diberi penjelasan. Pengujian normalitas data dilakukan dengan melihat selebaran standarrized residual. Apabila selebaran standarrized residual berada dalam kisaran garis normal, maka data mempunyai distribusi normal, Gujarati, (1999:342).

b. Uji Multikolinearitas

Uji ini dimaksudkan untuk mengetahui adanya hubungan yang kuat antara variabelvariabel independen dalam persamaan regresi untuk mendeteksi apakah antara variabel-variabel dependen yang digunakan 
mempunyai kolinearitas yang tinggi atau tidak, dapat dengan menggunakan Variance Inflation Factor (VIF) dan Person Correlation Matrik. Semakin besar nilai VIF maka semakin bermasalah atau semakin tinggi kolinearitas antar variabel independen. Jika nilai VIF sama dengan satu, menunjukkan tidak adanya kolinearitas antar variabel independen, dan bila nialai VIF kurang dari sepuluh maka tingkat kolinearitas belum tergolong berbahaya. Person Correlation Matrik digunakan untuk mengetahui nilai koefisien antar variabel independen. Jika nilai koefisien lebih kecil dari 0,85 tidak terkena multikolinearitas, Gujarati, (1999:342).

\section{Hasil dan Pembahasan}

\section{Karakteristik Responden}

Tabel 3. Karakteristik responden

\begin{tabular}{|c|l|c|c|}
\hline No & \multicolumn{1}{|c|}{ Uraian } & Frekuensi & Persentase \\
\hline 1. & Jenis kelamin Anda & & \\
& 1. Laki-laki & 18 & 38.3 \\
& 2. Perempuan & 29 & 61.7 \\
\hline 2. & Status Anda & 21 & \\
& 1. Belum Kawin & 26 & 44.7 \\
& 2. Kawin & 2 & 55.3 \\
\hline 3. & Pendidikan terakhir Anda & \\
& 1. SLTP & 12 & 4.3 \\
2. SLTA & 21 & 25.5 \\
3. Diploma III & 11 & 44.7 \\
4. Sarjana & 1 & 23.4 \\
5. Pascasarjana & 47 & 2.1 \\
\hline \multicolumn{2}{|l|}{ Jumlah } & & 100.0 \\
\hline
\end{tabular}

Sumber: Data Primer, 2018 (diolah)

Berdasarkan tabel karakteristik responden dapat dijelaskan bahwa hasil penelitian terhadap 47 orang karyawan PT. Bank Mandiri (Persero) Cabang Banda Aceh seperti yang tersaji pada tabel di atas dapat dijelaskan bahwa sebanyak 18 orang (38.3\%) laki-laki dan sebanyak 29 orang $(61.7 \%)$ terdiri dari perempuan. Mengenai status perkawinan dapat dijelaskan bahwa sebanyak 21 orang $(44.7 \%)$ berstatus menikah dan sebanyak 26 orang $(55.3 \%)$ responden berstatus belum menikah, dengan demikian responden dengan status sudah menikah lebih dominan dibandingkan dengan responden yang berstatus belum menikah.

Mengenai pendidikan terakhir responden dapat dijelaskan bahwa sebanyak 2 orang $(4.3 \%)$ berpendidikan terakhir SLTP, sebanyak 12 orang $(25.5 \%)$ berpendidikan terakhir SLTA, kemudian sebanyak 21 orang $(44.7 \%)$ berpendidikan terakhir Diploma III, sebanyak 11 orang (23.4\%) berpendidikan terakhir Sarjana dan responden dengan pendidikan terakhir Pascasarjana sebanyak 1 orang (2. 1\%) dari jumlah sampel yang diteliti.

\section{Hasil Pengujian Instrumen}

Menurut Arikunto (2005) kualitas data yang diperoleh dari penggunaan instrumen penelitian dapat dievaluasi melalui uji validitas dan uji reliabilitas (uji kehandalan) berdasarkan koefisien Cronbach Alpha yang lazim digunakan dalam penelitian ilmu-ilmu social

Tabel 4. Hasil uji validitas

\begin{tabular}{|c|c|c|c|c|c|}
\hline \multicolumn{2}{|c|}{ No. Pernyataan } & Variabel & $\begin{array}{c}\text { Koefisien } \\
\text { Korelasi }\end{array}$ & $\begin{array}{c}\text { Nilai Kritis } 5 \% \\
(\mathrm{~N}=47)\end{array}$ & Ket \\
\hline 1. & A1 & \multirow{5}{*}{$\mathrm{X} 1$} & 0.756 & 0.288 & Valid \\
\hline 2. & A2 & & 0.728 & 0.288 & Valid \\
\hline 3. & A3 & & 0.494 & 0.288 & Valid \\
\hline 4. & A4 & & 0.664 & 0.288 & Valid \\
\hline 5. & A5 & & 0.584 & 0.288 & Valid \\
\hline 6. & B1 & \multirow{4}{*}{$\mathrm{x} 2$} & 0.436 & 0.288 & Valid \\
\hline 7. & B2 & & 0.676 & 0.288 & Valid \\
\hline 8. & B3 & & 0.749 & 0.288 & Valid \\
\hline 9. & B4 & & 0.796 & 0.288 & Valid \\
\hline 10. & C 1 & \multirow{4}{*}{$\mathrm{Y}$} & 0.756 & 0.288 & Valid \\
\hline 11 & C2 & & 0.680 & 0.288 & Valid \\
\hline 12. & C3 & & 0.776 & 0.288 & Valid \\
\hline 13. & C4 & & 0.703 & 0.288 & Valid \\
\hline
\end{tabular}

Sumber: Data Primer, 2018 (diolah)

Berdasarkan tabel di atas dapat dijelaskan bahwa semua variabel yang koefisien korelasi di atas dari nilai kritis korelasi product moment yaitu sebesar 0.288 sehingga semua pertanyaan yang terkandung dalam kuesioner penelitian ini dinyatakan valid untuk dilanjutkan penelitian yang lebih mendalam.

Tabel 5. Reliabilitas Variabel Penelitian (Alpha)

\begin{tabular}{clcccc}
\hline No. & \multicolumn{1}{c}{ Variabel } & $\begin{array}{c}\text { Rata- } \\
\text { rata }\end{array}$ & $\begin{array}{c}\text { Item } \\
\text { Variabel }\end{array}$ & $\begin{array}{c}\text { Nilai } \\
\text { Alpha }\end{array}$ & Kehandalan \\
\hline 1. & Kepemimpinan Konsultatif $\left(\mathrm{x}_{1}\right)$ & 4.217 & 5 & 0.636 & Handal \\
2. & Tuntutan Tugas $\left(\mathrm{x}_{2}\right)$ & 4.064 & 4 & 0.601 & Handal \\
3. & Komitmen Karyawan $\left(\mathrm{x}_{\mathrm{a}}\right)$ & 3.920 & 4 & 0.696 & Handal \\
\hline
\end{tabular}

Sumber: Data Primer, 2018 (diolah)

Berdasarkan analisis reliabilitas dapat diketahui bahwa alpha untuk masing- $\neg$ masing variabel dapat dilihat dari beberapa variabel yaitu variabel kepemimpinan konsultatif (xl) diperoleh nilai alpha sebesar 63.6 persen, variabel tuntutan tugas $(\mathrm{x} 2)$ diperoleh nilai alpha sebesar 60. 1 persen, dan variabel komitmen karyawan $(\mathrm{Y})$ diperoleh nilai alpha sebesar 69.6 persen. Dengan demikian pengukuran reliabilitas terhadap variabel penelitian menunjukkan bahwa pengukuran keandalan memenuhi kredibilitas Cronbach Alpha dimana nilai alphanya lebih besar dari Alpha 0.60 persen.

\section{Pengujian Multikolinearitas}

Pengujian berikut ini akan menguji mengenai multikulinearitas yaitu diuji dengan melihat VIF dari masing-masing variabel independent terhadap 
variabel dependent. Bila VIF $<5$ maka tidak terjadi multikulinearitas atau non multikulinearitas (Santoso, 2000). Hasil pengujian ditunjukkan pada tabel berikut:

\begin{tabular}{|c|c|c|c|}
\hline Variabel Bebas & Tolerance & VIF & Keterangan \\
\hline Kepemimpinan Konsultatif & 0.945 & 1.058 & Non Multikolinieritas \\
\hline Tuntutan Tugas & 0.945 & 1.058 & Non Multikolinjentas \\
\hline
\end{tabular}

Berdasarkan tabel diatas dapat dijelaskan bahwa semua indikator variabel yang digunakan dalam penelitian ini tidak terjadi Multikolinieritas (Non Multikolinieritas), karena mempunyai nilai Variance Infalting Factor kurang dari 5, sebagai dipersyaratkan dalam penelitian ini. Kemudian dalam penelitian ini juga diketahui bahwa nilai tolerance pada pengujian multikolinieritas juga menunjukkan nilai lebih besar dari 0.5.

\section{Pembahasan}

Dalam rangka meningkatkan komitmen organisasi karyawan PT. Bank Mandiri (Persero) Cabang Banda Aceh, maka perlu dilihat variabel yang mempengaruhi komitmen karyawan PT. Bank Mandiri (Persero) Cabang Banda Aceh tersebut, untuk mengetahui pengaruh variabel bebas yaitu kepemimpinan konsultatif (x1), tuntutan tugas (x2), terhadap komitmen organisasi karyawan PT. Bank Mandiri (Persero) Cabang Banda Aceh (Y). Pengaruh masing-masing variabel bebas terhadap variabel terikat secara terinci dapat dilihat pada tabel 7 berikut ini:

Tabel 7. Pengaruh Variabel Bebas Terhadap Komitmen Karyawan PT. Bank Mandiri (persero) Cabang Banda Aceh

\begin{tabular}{lccccc}
\hline \multicolumn{1}{c}{ Nama Variabel } & B & $\begin{array}{c}\text { Standar } \\
\text { Error }\end{array}$ & $\mathrm{t}_{\text {hitung }}$ & $\mathrm{t}_{\text {tabel }}$ & Sig \\
\hline Konstanta (a) & 2.546 & 0215 & 11.818 & 2.012 & 0.000 \\
Kepemimpinan konsultatif $\left(\mathrm{X}_{1}\right)$ & 0.119 & 0.041 & 2.927 & 2.012 & 0.005 \\
Tuntutan togas $\left(\mathrm{X}_{2}\right)$ & 0.216 & 0.048 & 4.526 & 2.012 & 0.000 \\
\hline Sumber: Data Primer, 2018 (diolah) & & & &
\end{tabular}

Dari hasil perhitungan statistik dengan menggunakan bantuan program SPSS seperti terlihat pada tabel di atas, maka diperoleh persamaan regresi berganda sebagai berikut.

$\mathrm{Y}=2.546+0.119 \mathrm{x} 1+0.216 \mathrm{x} 2$

Dari persamaan regresi di atas dapat diketahui hasil penelitian sebagai berikut:

1. Koefisien Regresi ( $\beta$ ):

a. Konstanta sebesar 2.546. Artinya jika faktor-faktor kepemimpinan konsultatif (xl), tuntutan tugas (x2), dianggap konstan, maka besarnya komitmen karyawan PT. Bank Mandiri (Persero) Cabang Banda Aceh adalah sebesar 2.546 pada satuan skala likert atau komitmen karyawan PT. Bank Mandiri (Persero) Cabang Banda Aceh masih rendah. b. Koefisien regresi kepemimpinan konsultatif (x1) sebesar 0.119. Artinya bahwa setiap 100\% perubahan (kebijakan kepemimpinan konsultatif) dari setiap karyawan secara relatif akan meningkatkan komitmen karyawan PT. Bank Mandiri (Persero) Cabang Banda Aceh, sebesar 11.9\%, dengan demikian semakin baik kepemimpinan konsultatif yang diberikan oleh pihak PT.. Bank Mandiri (Persero) Cabang Banda Aceh, akan semakin meningkatkan komitmen karyawan PT. Bank Mandiri (Persero) Cabang Banda Aceh tersebut.

c. Koefisien regresi tuntutan tugas (x2) sebesar 0.216. Artinya setiap 100\% perubahan (perbaikan, karena tanda + ) setiap adanya tuntutan tugas maka secara relatif akan meningkatkan komitmen karyawan PT. Bank Mandiri (Persero) Cabang Banda Aceh sebesar 21.6\%, jadi dengan semakin tuntutan tugas yang dilakukan oleh pihak PT. Bank Mandiri (Persero) Cabang Banda Aceh, maka secara relatif akan meningkatkan komitmen karyawan PT. Bank Mandiri (Persero) Cabang Banda Aceh.

Berdasarkan hasil analisis di atas dapat diketahui bahwa dari dua variabel yang diteliti bahwa tuntutan tugas mempunyai pengaruh dominan terhadap peningkatan komitmen karyawan PT. Bank Mandiri (Persero) Cabang Banda Aceh, sedangkan varibale kepemimpinan konsultatif mempunyai pengaruh lebih kecil terhadap komitmen karyawan dengan nilai koefisien regresi sebesar 0.216 .

\section{Koefisien Korelasi dan Determinasi}

Sedangkan untuk melihat hubungan dan pengaruh dari variabel bebas terhadap komitmen karyawan PT. Bank Mandiri (Persero) Cabang Banda Aceh berdasarkan korelasi dan determinasi seperti dijelaskan pada tabel berikut ini :

Tabel 8. Model Summa

\begin{tabular}{|c|c|c|c|c|c|}
\hline $\mathrm{R}$ & $\mathrm{R}_{\text {squere }}$ & Adjusted $\mathrm{R}^{2}$ & $\begin{array}{l}\text { Std. Error } \\
\text { of the } \\
\text { estimate }\end{array}$ & DW & Keterangan \\
\hline 0.677 & 0.459 & 0.434 & 0.158 & 1.954 & $\begin{array}{l}\text { Korelasi } \\
\text { Kuat }\end{array}$ \\
\hline
\end{tabular}

a. Koefisien korelasi (R) $=0.677$ yang menunjukkan bahwa derajat hubungan (korelasi) antara variabel bebas dengan varibel terikat sebesar $67.7 \%$. Artinya komitmen karyawan PT. Bank Mandiri (Persero) Cabang Banda Aceh mempunyai hubungan yang sangat erat dengan faktor-faktor kepemimpinan konsultatif (x1), tuntutan tugas (x2) sehingga berpengaruh terhadap peningkatan komitmen organisasi karyawan. 
b. Koefisien Determinasi $(\mathrm{R} 2)=0.459$. Artinya sebesar $45.9 \%$ perubahan-perubahan dalam variabel terikat (komitmen karyawan PT. Bank Mandiri (Persero) Cabang Banda Aceh dapat dijelaskan oleh perubahan-perubahan dalam faktor kepemimpinan konsultatif (x1), tuntutan tugas (x2). Sedangkan selebihnya yaitu sebesar 54. 1\% dijelaskan oleh faktorfaktor lain diluar dari dua variabel yang dijadikan indikator penelitian artinya masih ada variabel yang dapat mempengaruhi komitmen karyawan PT. Bank Mandiri (Persero) Cabang Banda Aceh.

\section{Hasil Uji Statistik}

Untuk menguji faktor-faktor yang mempunyai pengaruh terhadap komitmen karyawan PT. Bank Mandiri (Persero) Cabang Banda Aceh secara parsial (masing ר-masing variabel) dapat dilihat dari hasil uji-t. Hasil perhitungan yang diperlihatkan pada tabel di atas, dimana dapat diketahui besarnya nilai thitung untuk masing-masing variabel dengan tingkat kepercayaan atau signifikansi sebesar $\alpha=5 \%$.

a. Hasil penelitian terhadap variabel kepemimpinan konsultatif (x1) diperoleh nilai thitung sebesar 2.927 sedangkan ttabel, = 2.012, hasil perhitungan ini menunjukkan bahwa thitung $>$ ttabel, dengan tingkatan signifikansi sebesar 0.005 atau probabilitas jauh dibawah $\alpha=5 \%$ Dengan demikian hasil perhitungan statistik menunjukkan bahwa secara parsial variabel kepemimpinan konsultatif berpengaruh secara signifikan terhadap peningkatan komitmen karyawan PT. Bank Mandiri (Persero) Cabang Banda Aceh.

b. Temuan hasil penelitian terhadap variabel tuntutan tugas ( $\mathrm{x} 2$ ) diperoleh nilai thitung sebesar 4.526 sedangkan ttabel sebesar 2.012, hasil perhitungan ini menunjukkan bahwa thitung $>$ ttabel, dengan signifikansi sebesar 0.000 atau probabilitas dibawah $\alpha 5 \%$. Dengan demikian hasil perhitungan statistik menunjukkan bahwa secara parsial variabel tuntutan tugas berpengaruh secara signifikan terhadap peningkatan komitmen karyawan PT. Bank Mandiri (Persero) Cabang Banda Aceh.

Berdasarkan uraian statistik di atas, memperlihatkan bahwa secara parsial masing-masing variabel mempunyai pengaruh secara signifikan terhadap peningkatan komitmen karyawan PT. Bank Mandiri (Persero) Cabang Banda Aceh, dan variabel yang mempunyai pengaruh yang sangat dominan berdasarkan hasil uji secara parsial adalah variabel tuntutan tugas terhadap karyawan dengan nilai thitung sebesar 4.526 dengan tingkat signifikansi atau probabilitas sebesar 0.000 , dan variabel kepemimpinan konsultatif dengan nilai thitung sebesar 2.927 dengan tingkat signifikansi atau probabilitas sebesar 0.005 .

3. Pengujian Secara Simultan

Untuk menguji hipotesis mengenai pengaruh kepemimpinan konsultatif dan tuntutan tugas terhadap Komitmen karyawan PT. Bank Mandiri (Persero) Cabang Banda Aceh, maka dapat dijelaskan pada tabel berikut ini :

Tabel 9. Analisis Of Variance (ANOVA)

\begin{tabular}{lcccccc}
\hline \multicolumn{1}{c}{ Model } & $\begin{array}{c}\text { Sum of } \\
\text { Squares }\end{array}$ & Df & $\begin{array}{c}\text { Maen } \\
\text { Squares }\end{array}$ & $\mathrm{F}_{\text {hitung }}$ & F,abe, & Sig. \\
\hline Regresi & 0.928 & 2 & 0.464 & 18.638 & 3.209 & 0.000 \\
Sisa & 1.095 & 44 & 0.025 & & & \\
Total & 2.023 & 46 & & & & \\
\hline
\end{tabular}

Berdasarkan hasil pengujian secara simultan

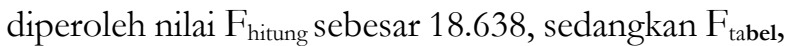
pada tingkat signifikansi $\alpha=5 \%$ adalah sebesar 3.209 Hal ini memperlihatkan, berdasarkan perhitungan uji statistik $\mathrm{F}_{\text {hitung }}$ menunjukkan bahwa $\mathrm{F}_{\text {hitung }}>\mathrm{F}_{\text {tabel, }}$ dengan tingkat probabilitas 0.000 . Dengan demikian hasil perhitungan ini dapat di ambil suatu keputusan bahwa hipotesis alternatif yang diajukan dapat diterima dan hipotesis nol ditolak, artinya bahwa kepemimpinan konsultatif (x1), tuntutan tugas (x2), secara bersama-sama berpengaruh secara signifikan terhadap komitmen karyawan Bank Mandiri (Persero) Cabang Banda Aceh.

\section{Pembuktian Hipotesis}

Berdasarkan hasil uji statistik baik secara simultan (uji-F statistik), maupun secara parsial dapat diperoleh suatu kesimpulan bahwa hipotesis yang diajukan dinyatakan :

1. Bahwa kepemimpinan konsultatif, tuntutan tugas, berpengaruh secara signifikan terhadap Komitmen karyawan PT. Bank Mandiri (Persero) Cabang Banda Aceh dengan diperoleh nilai $F_{\text {hitung }}$ sebesar 18.638 dan $F_{\text {tabel }}$ sebesar 3.209 dengan demikian $\mathrm{F}_{\text {hitung }}>\mathrm{F}_{\text {tabel, }}$, maka hipotesis yang diajukan terima.

2. Secara parsial variabel dominan yang mempengaruhi komitmen karyawan PT. Bank Mandiri (Persero) Cabang Banda Aceh adalah variabel tuntutan tugas dengan diperoleh nilai koefisien regresi sebesar 0.216 .

Dengan demikian kepemimpinan konsultatif yang dapat mengelola sumber daya manusia dan mau menyerap aspirasai bawahan akan mampu meningkatkan komitmen karyawan secara signifikan, sedangkan tuntutan tugas yang diberikan oleh pimpinan bank tersebut juga mempunyai pengaruh yang signifikan terhadap komitmen karyawan PT. Bank Mandiri (Persero) Cabang Banda Aceh, hal ini mengingat kepemimpinan konsultatif dan tuntutan 
tugas merupakan salah satu faktor yang dapat menunjang peningkatan komitmen karyawan PT. Bank Mandiri (Persero) Cabang Banda Aceh.

\section{Implikasi Penelitian}

Hasil penelitian menunjukkan bahwa gaya kepemimpinan konsultatif dan tuntutan tugas dapat berpengaruh terhadap peningkatan komitmen karyawan terhadap PT. Bank Mandiri (Persero) Cabang Banda Aceh, hal ini dikarenakan kepemimpinan yang selama ini diterapkan dapat diterima oleh karyawan, karena dengan kepemimpinan yang dijalankan oleh pimpinan bank saat ini telah membawa dampak yang positif.

Sedangkan tuntutan yang diberikan oleh pimpinan kepada setiap karyawan juga dapat memberikan dampak positif terhadap komitmen karyawan terhadap perusahaan, hal ini dikarenakan tuntutan tugas akan memberikan tanggung jawab kepada karyawan untuk dapat menjalankan tugas dan tanggung jawab kepada setiap karyawan.

\section{Kesimpulan}

1. Berdasarkan hasil analisis regresi linier berganda diperoleh penjelasan bahwa semua variabel yang diteliti yaitu kepemimpinan konsultatif $\left(\mathrm{x}_{1}\right)$ dan tuntutan tugas $\left(\mathrm{x}_{2}\right)$ mempunyai korelasi yang kuat terhadap komitmen karyawan PT. Bank Mandiri (Persero) Cabang Banda Aceh.

2. Berdasarkan hasil uji-F (simultan) menunjukkan bahwa semua variabel yang diteliti mempunyai pengaruh yang signifikan terhadap peningkatan komitmen karyawan PT. Bank Mandiri (Persero) Cabang Banda Aceh dengan nilai $\mathrm{F}_{\text {hitung }}>$ $\mathrm{F}_{\text {tabet, }}$ pada tingkat signifikansi $\alpha=5 \%$.

3. Berdasarkan hasil uji-t (secara parsial) variabel yang sangat signifikan berpengaruh terhadap komitmen karyawan PT. Bank Mandiri (Persero) Cabang Banda Aceh adalah variabel tuntutan tugas dengan diperoleh nilai $t_{\text {hitung }}$ lebih besar dibandingkan dengan variabel kepemimpinan konsultatif mempunyai nilai thitung yang lebih kecil.

\section{Daftar Pustaka}

Arikunto Suharsimi. 2005. Prosedur Penelitian Suatu Pendekatan Praktek. Jakarta : PT. Bina Aksara.
Dessler, Garry. 2007. Manajemen Sumber Daya Manusia (Ted.). PT. Indeks, Jakarta.

Garvin. 2000. Business and Society, Fifth Edition, Mc.Graw-Hill, Japan

Ghozali, Imam. 2001. Aplikasi Anatisis Multivariate Dengan Program SPSS. Semarang: Badan Penerbit Universitas Diponegoro.

Gibson, Ivannenich, Donnelly. 2003. Organisasi, Edisi ke Lima Penerbit Erlangga, Jakarta.

Handoko, T. Hani. 2004. Manajemen Sumber Daya Manusia. Yogyakarta: Badan Penerbit Fakultas Ekonomi.

Hersey dan Blanchard 2005. Management at Organizational Behavior Human Resources. Engglewood Cliffs, New Jersey : Prentice Hall Inc.

Keith Davis, William Frederick. 2001. Perilaku Dalam Organisasi, Edisi ke tujuh, Jilid kedua. Erlangga, Jakarta.

Koesmono, H. Teman. 2007. Pengaruh Kepemimpinan dan Tuntutan Tugas Terhadap Komitmen Organisasi Dengan Variabel Moderasi Motivasi Perawat Rumah Sakit Swasta Surabaya, Jurnal Manajemen dan Kewirausahaan, Volume 9 No. 1 Maret, 2007.

Libby R. Lipe. 2002. Aspek Lingkungan Kerja Dalam Organisasi. (Ted), Edisi ketiga. Erlangga, Jakarta

Malhotra, K, Naresh. 2005. Riset Pemasaran Pendekatan Terapan, PT. Indeks Kelompok Gramedia, Jakarta.

Manullang. 2004. Manajemen Personalia, Jakarta: Ghalia Indonesia.

Mathis, Robert L, Jackson, John H. 2002. Manajemen Sumber Daya Manusia. Jakarta: Salemba Empat.

Mitchell. 2002. Management and Supervisor. Alih Bahasa : Mas'ud. Jakarta: PT. Pertija. 
Mowday R. \& Steers. 2002. Employ Organization Linkages: The Psychology of Commitment Abstein and Turn Over, Academic, inc, London.

Nawawi, dan Hadari. 2005. Administrasi dan Organisasi Bimbingan dan Penyuluhan, Jakarta, Ghalia Indonesia.

Pantja Djati dan M. Khuspini. 2003. Pengaruh Kepuasan Kompensasi, Komitmen Organisasi Dan Iklim Organisasi Terhadap Prestasi Kerja Karyawan. Jurnal Ilmiah, Universitas Kristen Petra Surabaya.

Ranupandoyo, Heidjrachman dan Suad Husnan. 2007, Manajemen Personalia, Fakultas Ekonomi UGM (BPFE), Yogyakarta.

Rivai, Veithzal. 2005. Kepemimpinan dan Perilaku Organisasi (Cetakan Pertama). Jakarta: PT Raja Grafindo Persada.

Robbins, Stephen P. 2006. Perilaku Organisasi. PT. Indeks Jakarta.

Saydan. 2006. Manajemen Sumber Daya Manusla, Jakarta, Penerbit Jambatan.
Santoso, Singgih. 2000. Riset Pemasaran, Aplikasi Dengan SPSS Versi 15.0. PT. Elek Media Komputindo, Jakarta.

Siagian, Sondang P. 2003. Teori Motivasi dan Aplikasinya. Jakarta Rineka Cipta.

Steers dan Porter. 2002. A Theory of Leadership Effectiveness. New York : McGraw-Hill Boah Company.

Strauss dan Jayless. 2006. Management. Alih Bahasa : Hutauruk. Jakarta : Erlangga.

Thomson. 2001. Kepemimpinan Dalam Manajemen. Jakarta: PT. Rineka Cipta.

Umar, Husein. 2001. RisetSumber Daya Manusia, Penerbit, Rineka Cipta, Jakarta.

Wahjosumidjo. 2002. Kepemimpian dan Motivasi, Cetakan III, Jakarta: Ghalia Indonesia.

Winardi. 2000. Motivasi dan PemoNvasian dalam Manajemen (Cetakan Pertama). Jakarta: PT Raja Grafindo Persada. 